\title{
IMPLEMENTASI LAN KEAMANAN JARINGAN LAN BERBASIS ACLS DAN VLAN
}

\author{
BUDIONO \\ 185100007 \\ Fakultas Komputer \\ budiono.students@umitra.ac.id
}

\begin{abstract}
Manajemen jaringan di era jaringan komputer modern adalah hal yang sangat penting karena setiap perangkat dapat berkoneksi dengan perangkat lain yang berada di seluruh dunia melalui kecanggihan teknologi internet. Tentu saja dengan kemajuan ini membutuhkan suatu sistem pemantauan jaringan komputer yang membantu administrator jaringan dalam mengelola Local Area Network (LAN). Permasalahan yang sering timbul adalah kesulitan untuk mengetahui status open port disaat terjadi trouble ataupun serangan di dalam jaringan karena jumlah port jaringan mencapai 65.536, sehingga membutuhkan waktu yang lebih lama untuk melakukan perbaikan jaringan. Selain itu kebutuhan akan suatu sistem terintegrasi dalam pemantauan proses serta statistik port dalam Local Area Network (LAN) menjadi landasan dalam penelitian ini sehingga dapat meminimalisasi penggunaan sistem yang terlalu banyak dalam pemantauan jaringan komputer. Hasil dari penelitian ini adalah suatu sistem baru hasil modifikasi dari Mandau Registry Tools and Information System dengan menambahkan layanan seperti informasi protokol, statistik port, dan informasi tentang Domain Name System (DNS) dan penambahan layanan Access Control Lists (ACLs) dengan Fail2Ban. Menggunakan tahapan perencanaan, analisis, desain, implementasi, dan pengujian sebagai metode pengembangan sistem, diharapkan penelitian ini dapat membantu pemantauan dan keamanan Local Area Network (LAN) yang lebih baik dengan kompleksitas informasi proses jaringan dan statistik port yang dihasilkan.
\end{abstract}

Lan memiliki kecepatan perpindahan data yang lebih tinggi Berfungsi. dengan baik tanpa adanya jalur telekomunikasi kelainan tidak membutuhkan akses internet.Local area network Lan merupakan sebuah komputer yang saling dihubungkan bersama di dalam satu area tertentu yang tidak begitu luas secara garis besar terdapat dua tipe jaringan atau lan bubar dan jaringan client server.Pada jaringan peer to peer setiap komputer yang terhubung ke jaringan dapat bertindak baik sebagai workstation maupun server. Sedangkan pada Jaringan client server hanya satu komputer yang bertugas sebagai server dan komputer lain berperan sebagai workstation.

Kata Kunci-Keamanan Jaringan Komputer, Statistik Port, Local Area Network, Mandau Registry Tools and Information System, Fail2Ban 
A. PENDAHULUAN

Materi Kuliah Section 01 Membahas Tentang Dunia teknologi modern saat ini sangat diperlukan untuk pertukaran informasi yang cepat, instan, dan akurat antara orang-orang di seluruh dunia. Dengan tuntutan teknologi yang semakin tinggi, maka dibutuhkan teknologi yang dapat membantu kerja manusia untuk diwujudkan dalam pertukaran informasi. Internet adalah teknologi yang paling cepat berkembang saat ini yang mendukung pertukaran informasi melalui jaringan komputer yang canggih, cepat, dan efisien ke wilayah yang sangat luas.

Dengan luasnya cakupan teknologi ini, maka sumber daya perangkat keras yang dibutuhkan juga harus canggih dan bagus. Masalahnya adalah biaya, karena tidak semua komputer dalam jaringan memiliki sumber daya yang canggih

dan baik. Masalah ini diakomodasi dengan jaringan komputer client-server. Komputer server akan lebih baik dari komputer klien karena memiliki peran untuk menyediakan layanan ke komputer klien yang ada di jaringan komputer. Administrator berperan mengendalikan server dan bertanggung jawab untuk memantau jaringan agar sistem tetap berjalan baik, aman, dan sesuai dengan aturan yang ada. Beberapa kesulitan yang muncul adalah pada pemantauan sumber daya server jaringan komputer. Karena selain mengendalikan server, administrator juga ditugaskan untuk menjaga keamanan jaringan komputer dari serangan oleh pihak luar.

Saat ini banyak serangan jaringan komputer yang memanfaatkan port terbuka di jaringan komputer. Bahkan dikatakan hampir semua serangan yang terjadi pada jaringan komputer melalui port yang terbuka. Serangan seperti Denial of Service (DoS), Back Door, Spoofing, Brute Force, SQL Injection, Port Scanning, Network Flooding, hingga virus mengeksploitasi kerentanan port terbuka di jaringan komputer. Port dapat digambarkan sebagai jendela rumah, sehingga jumlah itu sangat banyak karena port di jaringan komputer bernilai 16 (enam belas) bit, sehingga jumlah total port dalam jaringan komputer adalah 65.536 buah [1]. Serangan melalui port biasanya merusak atau mencuri informasi dari server seperti server email, server data, server web, atau pencurian pengguna dan kata sandi sistem untuk tujuan tertentu [2]. Tentu saja permasalahan keamanan tersebut harus dapat diakomodasi oleh administrator agar stabilitas jaringan tetap berjalan dengan baik. Dengan tugas berat seorang administrator yang harus mengendalikan, memantau, dan 
mengamankan jaringan komputer dari serangan yang terjadi, dibutuhkan sistem pemantauan jaringan komputer untuk membantu administrator terutama dalam memantau port dan proses di Local Area Network (LAN).

\section{B. PEMBAHASAN / STUDI} KASUS

Pembahasan ini berisi implementasi desain sistem dan

diskusi tentang pengujian sistem. Implementasi dan pengujian

sistem ini dijelaskan melalui print screen gambar pada setiap halaman aplikasi dan tabel hasil analisa disertai dengan penjelasannya.

Hasil dari penelitian ini menghasilkan beberapa fasilitas yaitu pemantauan proses pada sistem operasi, sistem pemantauan perangkat keras, dan sistem pemantauan jaringan. Fasilitas pertama dari sistem ini adalah halaman untuk memantau proses yang terjadi di sistem operasi. Halaman ini sudah disediakan oleh Mandau Registry Tools and Information System. Penjelasan ini ditemukan pada Gambar.

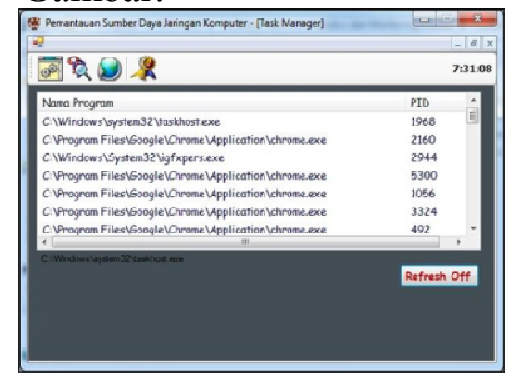

Halaman proses sistem operasi yang terdapat pada Gambar 6 adalah fasilitas yang digunakan untuk pemantauan proses pada sistem operasi. Fungsionalitas halaman ini mirip dengan Windows Task Manager.

Fasilitas lain yang terdapat dalam sistem pemantauan jaringan komputer ini adalah informasi tentang perangkat keras komputer. Fasilitas ini ditunjukkan pada Gambar.

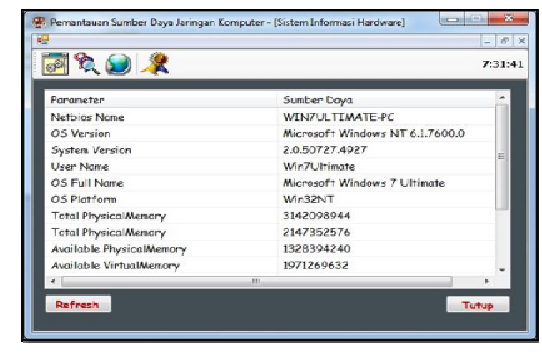

Gambar berisi informasi rinci tentang perangkat keras server komputer. Informasi pada halaman ini antara lain jenis sistem operasi, kondisi RAM, dan kondisi harddisk yang membantu administrator dalam memantau kondisi perangkat keras.

\section{ID SECURITY}

QWTD4452377-ASP-5244166

\section{KESIMPULAN}

Setelah mengamati hasil penelitian eksperimental dengan menggunakan beberapa rangkaian hasil evaluasi yang menghasilkan sistem pemantauan statistik port pada Local Area Network (LAN) dan implementasi 
Access Control Lists (ACLs) terhadap alamat IP yang pernah melakukan serangan, peneliti dapat menarik kesimpulan bahwa sistem hasil penelitian ini dapat digunakan untuk memberikan informasi rinci tentang kondisi Local Area Network (LAN) terutama dalam hal pemantauan port jaringan. Dengan modifikasi Mandau Registry Tools and Information System dari yang semula merupakan sistem untuk implementasi pemantauan proses, pemantauan hardware, dan pemantauan sistem operasi menjadi sistem yang lebih lengkap dengan penambahan fitur baru yaitu pemantauan port jaringan komputer. Sistem ini dapat membantu administrator dalam proses deteksi kerusakan dan serangan dengan melihat status dan jumlah port terbuka yang dihasilkan oleh sistem ini karena memiliki sensitivitas tinggi terhadap status port terbuka. Selain itu dengan implementasi Access Control Lists (ACLs) terhadap alamat IP yang pernah melakukan serangan membuat Local Area Network (LAN).

\section{E. DISKUSI}

Saya bersama teman saya bernama Maulidun nur mendiskusikan tentang Pengertian LAN suatu jaringan komputer dimana cakupan wilayah jaringan sangat kecil atau terbatas. Misalnya, jaringan komputer kantor, sekolah, rumah atau dalam suatu ruangan bangun pada sebuah lokasi rumah ataupun gedung perkantoran bisa diartikan juga sebagai sebuah sistem komunikasi komputer yang jaraknya dibatasi tidak lebih dari beberapa kilometer dan menggunakan koneksi high-speed antara 2 hingga 100 mbps iklan memiliki karakteristik yang membedakannya dengan jaringan MAN Network dan wan area network statistik LAN adalah sebagai berikut dalam ruang lingkup lebih sempit kantor kampus sekolah rumah sakit dan rumah.

Lan memiliki kecepatan perpindahan data yang lebih tinggi Berfungsi. dengan baik tanpa adanya jalur telekomunikasi kelainan tidak membutuhkan akses internet.Local area network Lan merupakan sebuah komputer yang saling dihubungkan bersama di dalam satu area tertentu yang tidak begitu luas secara garis besar terdapat dua tipe jaringan atau lan bubar dan jaringan client server.Pada jaringan peer to peer setiap komputer yang terhubung ke jaringan dapat bertindak baik sebagai workstation maupun server. Sedangkan pada Jaringan client server hanya satu komputer yang bertugas sebagai server dan komputer lain berperan sebagai workstation. 


\section{F. REFERENCE}

[1] O. M. Febriani and A. S. Putra, "Sistem Informasi Monitoring Inventori Barang Pada Balai Riset Standardisasi Industri Bandar Lampung," $J$. Inform., vol. 13, no. 1, pp. 9098, 2014.

[2] A.

S. Putra, "Paperplain: Execution Fundamental Create Application With Borland Delphi 7.0 University Of Mitra Indonesia," 2018.

[3] A. S. Putra, "2018 Artikel Struktur Data, Audit Dan Jaringan Komputer," 2018.

[4] A. S. Putra, "ALIAS MANAGER USED IN DATABASE DESKTOP STUDI CASE DB DEMOS."

[5] A. S. Putra, "COMPREHENSIVE SET OF PROFESSIONAL FOR DISTRIBUTE COMPUTING."

[6] A. S. Putra, "DATA ORIENTED RECOGNITION IN BORLAND DELPHI 7.0."

[7] A. S. Putra, "EMBARCADERO DELPHI XE 2 IN GPU-POWERED FIREMONKEY APPLICATION."

[8] A. S. Putra, "HAK ATAS KEKAYAAN INTELEKTUAL DALAM DUNIA TEKNOLOGY BERBASIS REVOLUSI INDUSTRI 4.0."

[9] A. S. Putra, "IMPLEMENTASI

PERATURAN

PERUNDANGAN UU. NO 31

\section{TAHUN 2000 TENTANG DESAIN INDUSTRI BERBASIS INFORMATION TECHNOLOGY."}

[10]

$\begin{array}{lr}\text { A. S. } & \text { Putra, } \\ \text { "IMPLEMENTATION } & \text { OF } \\ \text { PARADOX DBASE." } & \end{array}$

[11] A. S. Putra, "IMPLEMENTATION OF TRADE SECRET CASE STUDY SAMSUNG MOBILE PHONE."

[12] A. S. Putra, "IMPLEMENTATION

PATENT FOR APPLICATION WEB BASED CASE STUDI WWW. PUBLIKLAMPUNG. COM."

[13] A. S. Putra, "IMPLEMENTATION

SYSTEM FIRST TO INVENT IN DIGITALLY INDUSTRY." [14] A. S. Putra, "MANUAL REPORT \& INTEGRATED DEVELOPMENT

ENVIRONMENT BORLAND DELPHI 7.0."

[15] A. S. Putra, "PATENT AS RELEVAN SUPPORT RESEARCH."

[16] A. S. Putra, "PATENT FOR RESEARCH STUDY CASE OF APPLE. Inc."

[17] A. S. Putra, "PATENT PROTECTION FOR APPLICATION INVENT."

[18] A. S. Putra, "QUICK REPORT IN PROPERTY PROGRAMMING."

[19] A. S. Putra, "REVIEW CIRCUIT LAYOUT COMPONENT

REQUIREMENT ON ASUS NOTEBOOK."

[20] A. S. Putra, "REVIEW 


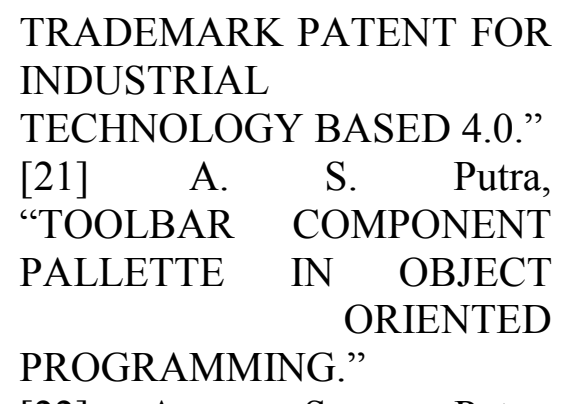

[22] A. S. Putra, "WORKING DIRECTORY SET FOR PARADOX 7."

[23] A. S. Putra, "ZQUERY CONNECTION

IMPLEMENTED

PROGRAMMING STUDI
[27] A. S. Putra, H. Sukri, and K. Zuhri, "Sistem Monitoring Realtime Jaringan Irigasi Desa (JIDES) Dengan Konsep Jaringan Sensor Nirkabel," IJEIS (Indonesian J. Electron. Instrum. Syst., vol. 8, no. 2, pp. 221-232.

[28] D. P. Sari, O. M. Febriani, and A. S. Putra, "Perancangan Sistem Informasi SDM Berprestasi pada SD Global Surya," in Prosiding Seminar Nasional Darmajaya, 2018, vol. 1, no. 1, pp. 289294.
[24] A. S. Putra, D. R. Aryanti, and I. Hartati, "Metode SAW (Simple Additive Weighting) sebagai Sistem Pendukung Keputusan Guru Berprestasi (Studi Kasus: SMK Global Surya)," in Prosiding Seminar Nasional Darmajaya, 2018, vol. 1, no. 1, pp. 85-97.

[25] A. S. Putra and O. M. Febriani, "Knowledge Management Online Application in PDAM Lampung Province," in Prosiding International conference on Information Technology and Business (ICITB), 2018, pp. 181-187.

[26] A. S. Putra, O. M. Febriani, and B. Bachry, "Implementasi Genetic Fuzzy System Untuk Mengidentifikasi Hasil Curian Kendaraan Bermotor Di Polda Lampung," SIMADA (Jurnal Sist. Inf. dan Manaj. Basis Data), vol. 1, no. 1, pp. 21-30, 2018. 